\title{
Analysis of the Results on Perioperative Blood Loss after a Total Knee Arthroplasty Employing Tranexamic Acid before or after Inflating the Tourniquet
}

Ana Torres*, Mariano Fernández-Fairén and Daniel Hernández Vaquero

Universitary Hospital Santa Lucia, Cartagena, Murcia, Spain

\begin{abstract}
Introduction: Tranexamic acid has showed its good results reducing blood loss in total knee arthroplasties. It has also probed being cost-effective (red cell concentrate: 350 euros/ TXA vial 3, 05 euros) but it remains not being clear at what time during the surgery we have to administrate it.

In this prospective, randomized study, we have investigated the effects of the use of tranexamic acid before or after inflating the tourniquet on blood loss, transfusion needs and thromboembolic complications after implanting a total knee arthroplasty.
\end{abstract}

120 patients were selected and assigned randomly in two groups: tranexamic acid employed before inflating (group 1) or just before deflating the tourniquet (Group 2).

Methods and materials: From May 2011 to May 2012, 80 patients ( 38 males, 42 females; aged 64-81 years, mean age 69, 2years) underwent to a total knee replacement. All of them had moderate-severe knee osteoarthritis. They were randomized divided into Group1 and Group 2 of 40 patients each. The patients in Group 1 received tranexamic acid (TXA) before inflating the tourniquet and TXA was administered on the patients in Group 25 minutes before deflating the tourniquet. TXA was used in both groups every 8 hours during the first three days postop.

Variables under comparison included haemoglobin determinations (pre, postop and fifth days after surgery), drainage blood volume, transfusion requirements and appearance of thromboembolic complications.

Results: The drainage blood loss was $364 \pm 186 \mathrm{ml}$ (Group 1) and $413 \pm 175 \mathrm{ml}$ (Group 2). The total blood loss was $573 \pm 159 \mathrm{ml}$ (Group 1) and $608 \pm 132$ (Group 2).

No statistical significant differences were found in the amount of blood at the drain and on the total blood loss. The haemoglobin values did not showed statistical significant differences between groups before surgery on the postop or 5 days after the surgery.

No significant difference in haemoglobin determinations (pre, postop and fifth days after surgery), drainage blood volume, transfusion requirements, deep-vein thrombosis, and pulmonary embolism was detected between the groups. One patient in group 1 received 1 unit of allogenic blood and one patient in group 2 received 3 units. No statistical significant difference was seen. Two patients in group 1 and three patients in group 2 had clinical symptoms of deep vein thrombosis. Only one patient in group 2 presented an eco-Doppler study positive for a lower limb thrombosis.

Conclusions: We conclude that there is no significant difference on blood loss, transfusion requirements and thromboembolic complications after performing a total knee arthroplastywhen thetranexamic acid is employed before inflating or just before releasing the tourniquet.

Keywords: Tranexamic acid; TKA; Effectiveness

\section{Introduction}

Performing a total knee replacement (TKR) supposes the loosening of 1500 to $1900 \mathrm{cc}$ of blood (drainage volume + haematoma formation) [1-3].

Some factors have being related to the TKR bleeding as: patients co-morbidities (cardiovascular, respiratory, hepatic and coagulation diseases), drugs (NSAIDs, salicilates, LMWH, antiagregants), anaesthetic technique (spinal or general), postoperative blood pressure (systolic under $150 \mathrm{mmHg}$ ) and surgical technique (use of cement, size of the incision, tourniquet time, haemostasia, tissue damage).

Nearly fifty present of the patients operated of a TKR need postoperative blood transfusion. Blood transfusion presents of disease transmission [4-6], ABO group incompatibility [7], infection due to inmunosupression $[8,9]$ and high costs.

Some solutions, as the administration of antifibrinolytic drugs (tranexamic acid), have been proposed to reduce the bleeding on a TKR surgery and to decrease the number of transfusions. Hyperfibrinolysis is considered being the major cause of postoperative bleeding after TKA surgery [10-14], the fibrinolytic system is activated in the first hours after surgery increasing the postoperative bleeding after remove the pneumatic tourniquet [15-17]. Tranexamic acid (TXA, trnas-4aminomethyl cyclohexane carboxylic acid), is a synthetic reversible inhibitor of fibrinolysis, that competitively blocks a lysine binding site of plasminogen [18]. It has been used during more than 20 years in cardiac surgery, urology, genecology, liver transplants, etc. This

*Corresponding author: Ana Torres, Universitary Hospital Santa Lucia, Cartagena, Murcia, Spain, Tel: 912-344-3197; E-mail: anatpz@gmail.com

Received December 29, 2013; Accepted January 28, 2014; Published February 05, 2014

Citation: Torres A, Fernández-Fairén M, Vaquero DH (2014) Analysis of the Results on Perioperative Blood Loss after a Total Knee Arthroplasty Employing Tranexamic Acid before or after Inflating the Tourniquet. Surgery Curr Res 4: 171 doi:10.4172/2161-1076.1000171

Copyright: $\odot 2014$ Torres A, et al. This is an open-access article distributed under the terms of the Creative Commons Attribution License, which permits unrestricted use, distribution, and reproduction in any medium, provided the original author and source are credited. 
Citation: Torres A, Fernández-Fairén M, Vaquero DH (2014) Analysis of the Results on Perioperative Blood Loss after a Total Knee Arthroplasty Employing Tranexamic Acid before or after Inflating the Tourniquet. Surgery Curr Res 4: 171. doi:10.4172/2161-1076.1000171

Page 2 of 4

medication reduces blood loss but it can also increase the risk of thromboembolic complications [19].

Multiple studies have been done to verify the efficacy of tranexamic acid and find the correct dose and the duration of treatment [1,2,20-24].

The first publishedstudies established the correct therapeutic dose of tranexamic acid at $10 \mathrm{mg} / \mathrm{kg}[25,26]$. But this dose maintains a correct plasma concentration of TXA just for only 3 hours [27] and this fact has been the argument to use higher doses of TXA.

More recent studies demonstrated that a tranexamic acid dose of 15 $\mathrm{mg} / \mathrm{kg}$ every 8 hours during 24 hours would be appropriate to reduce blood loss [16,28].

Hiippala et al. [20] proposed to maintain TXA for several days taking into account that the tourniquet application may affect haemostasis for a considerably longer time than the surgical procedure. Jansen et al. [15], employed TXA before and 72 hours after surgery demonstrating that the degree of blood loss correlated significantly with both fibrinogen and plasminogen concentrations during the first 24 hours. Research on tranexamic acid and thrombosis failed to show any thrombogenic effect $[22,23,29]$ but thrombotic complications were reported with therapy exceeding 24 hours [30,31].

Frequently, TXA was administered before the deflating of the tourniquet $[20,21,22-24]$. Knowing that tourniquet inflation stimulates the fibrinolytic system [32,33] Jansen et al. [15] employed TXA before inflating the tourniquet having good results and without increasing the number of thrombotic complications.

As no consensus has been reached on when starting to use the TXA and for how long we performed this study to analyse the results (blood loss, transfusion requirements and thromboembolic complications ) employing TXA before inflating the tourniquet or just before deflating it and maintaining the TXA in both groups during 24 hours.

\section{Patients and Methods}

A randomized clinical trial approved by the Hospital Ethics Committee was carried out with two groups: group 1 administrating tranexamic acid (TXA) before inflating the tourniquet and group 2 were the acid was given 5 minutes before deflating the tourniquet.

Patients with a coagulopathy, a thromboembolic event, treated with aspirin or non -steroidal agents the week before the surgery, a plasma creatinine greater than 115 micromol litre in men and 100 micromol litre in women, allergic to tranexamic acid, a hepatic or renal dysfunction, aserious cardiac or respiratory disease, an acute infection, a malignant disease or being treated with drugs affecting the coagulation system were excluded.

The patients included presented an anaesthetic risk (ASA) I or II, signed the informed consent and presented and osteoarthritic knee.

Patients were operated performing a unilateral total knee replacement between May 2011 and May 2012 by two senior surgeons following a standardized procedure in the same Hospital.

The sample size was calculated on the basis of the mean difference in the visible blood loss greater or equal to $300 \mathrm{ml}$ between the two study groups with a standard deviation of $500 \mathrm{ml}$, an alpha error of 0 , 05 and $90 \%$ statistical power: 30 patients were needed in each group. Estimating 10\% losses on the follow up, 80 patients wereincluded in our study.

Anumber was assigned to each patient following the order of inclusion in the study. The patients were randomized in two groups: one received tranexamic acid before inflating the tourniquet and the other, five minutes before the release of the tourniquet.

Twelve hours before the surgery a subcutaneous injection with $40 \mathrm{mg}$ of enoxaparin (Clexane, Sanofi-Aventis, S.A, Barcelona, Spain) was administrated. The antithrombotic prophylaxis with $40 \mathrm{mg}$ of enoxaparin per day was maintained during one month. Isobaric bupivacaine was employed to perform the subarachnoid spinal anaesthesia.

The antibiotic prophylaxis consisted in $2 \mathrm{~g}$ of cefazoline administrated 30 minutes before starting the surgery and 1 gr every 6 hours during the first day postop. In patients allergic to penicillin we employed $1 \mathrm{~g}$ of vancomicin one hour before surgery followed by $1 \mathrm{~g}$ every 12 hours during 24 hours.

Before inflating the pneumatic tourniquet to $300 \mathrm{mmHg}$, the patient leg was elevated during 5 minutes to allow a partial exanguination.

Posterior stabilized cemented (Palacoscement, Heraeus Medical, Hanau, Germany) knee prostheses Genesis II (Smith \& Nephew; Memphis, Tenn) were implanted. The wound was closed, one intraarticular drain at atmospheric pressure opened 30 minutes after the end of the surgical procedure was inserted and maintained for 24 hours and a compressive bandage was applied before release of the tourniquet.

Tranexamic acid at a dose of $15 \mathrm{mg} / \mathrm{kg}$ (Amchafibrin, Rottapharm, S.A,Barcelona,Spain ) was infused intravenous in $100 \mathrm{cc}$ saline 30 minutes before surgery in group one and five minutes before deflate the tourniquet in group 2. Then tranexamic acidwas used in both groups every 8 hours for 1 day with the same dose.

During the surgical intervention patients received a Ringer's solution at a rate of $4 \mathrm{ml} / \mathrm{kg} / \mathrm{h}$ for compensation of insensible fluid losses and crystalloids in equal volumes to compensate measured blood losses.

Patients were transfused an allogenic red blood concentrate of 250 $\mathrm{ml}$ if they reacheda haemoglobin level of less than $8 \mathrm{~g} / \mathrm{dl}$ or they present signs or symptons of hypoxia (tachycardia, dyspnoea or syncope) with a haemoglobin level of less than $10 \mathrm{~g} / \mathrm{dl}$.

Physiotherapy has started on the first postoperative day after removing the drainage.

Blood tests were performed the night before the surgery, 5 hours after the operation and 5 days after the surgical procedure.

Variables under comparison included haemoglobin determinations (pre, postop and fifth days after surgery), drainage blood volume, transfusion requirements and appearance of thromboembolic complications.

To estimate the blood loss wecalculated first the loss of $\mathrm{Hb}$ (grams) assuming that the blood volume on the fifth day after surgery was the same as before surgery [34] and employing the following formula [35]:

$\mathrm{Hb}_{\text {loss }}=\mathrm{BV} \times\left(\mathrm{Hb}_{\mathrm{B}}-\mathrm{Hb}_{5}\right) \times 0,001+\mathrm{Hb}_{\mathrm{t}}$

$\mathrm{Hb}_{\mathrm{p}}=$ Haemoglobin preop

$\mathrm{Hb}_{5}=$ Haemoglobin fifth day after surgery

$\mathrm{Hb}_{\mathrm{t}}=$ Haemoglobin transfused (every unit of banked blood is considered to contain $52 \mathrm{~g}$ of haemoglobin)

The blood loss $(\mathrm{ml})$ was related to the patient's preoperative $\mathrm{Hb}$ value $\left(\mathrm{Hb}_{\mathrm{p}}\right)$ following this formula: 
Citation: Torres A, Fernández-Fairén M, Vaquero DH (2014) Analysis of the Results on Perioperative Blood Loss after a Total Knee Arthroplasty Employing Tranexamic Acid before or after Inflating the Tourniquet. Surgery Curr Res 4: 171. doi:10.4172/2161-1076.1000171

Page 3 of 4

\section{Blood loss $=1000 \times \mathrm{Hb}_{\text {loss }} \mathrm{Hb}_{\mathrm{p}}$}

Patients were seen at the out-patient clinic 2 weeks after the surgery to check the presence of possible complications, particularly thrombosis and thromboembolisms.

All results were recorded and an Excel chart was done. A statistical analysis was performed describing the variables first. Then a Student t-test was used to assess the homogeneity and to compare the main results between the two groups for continuous variables. When the distribution was not normal, the Mann Whitney $U$ test was used to compare means. ANOVA test was used to compare means between different parameters. The square Chi test was used to compare percentages. In all cases, the level of statistical significance was 0,05 . Comparisons were made employing the SPSS v.18.0.

\section{Results}

The groups studied had similar characteristics before surgery with no statistically significant differences in demographics variables (Table $1)$.

The two groups were statistically comparable in operative time and duration of tourniquet inflation (Table 2). The drainage blood loss was 364 +/- $186 \mathrm{ml}$ (Group 1) and 413 +/- $175 \mathrm{ml}$ (Group 2).

The total blood loss was $573+/-159 \mathrm{ml}$ (Group 1) and $608+/$ 132(Group 2).

No statistical significant differences were found in the amount of blood at the drain and on the total blood loss.

The haemoglobin values did not showed statistical significant differences between groups before surgery on the postop or 5 days after the surgery (Table 3 ).

One patient in group 1 received 1 unit of allogenicblood (Haemoglobine postop=8) and one patient in group 2 received 3 units (Haemoglobine postop=7,8). No statistical significant difference was seen.

Two patients in group 1 and three patients in group 2 had clinical symptoms of deep vein thrombosis (oedema and painful calf). Only one patient in group 2 presented an eco-Doppler study positive for a lower limb thrombosis. All of them received one month treatment of low-molecular weight heparin at therapeutic dosage. 2 weeks after the surgery, at the out patient's clinic, only this patient continued with oedema and pain on his leg. The rest were asymptomatic. No pulmonary embolism was detected in our series.

\begin{tabular}{|l|c|c|c|}
\hline & Group 1 & Group 2 & P Value \\
\hline Sex (M/F) & $22 / 18$ & $16 / 24$ & 0.416 \\
\hline age & $68(64-81)$ & $70.5(64-81)$ & 0.124 \\
\hline weight & 74.3 & 77.8 & 0.386 \\
\hline height & 158.7 & 162.5 & 0.374 \\
\hline ASA (I/II) & $12 / 28$ & $9 / 31$ & 0.569 \\
\hline
\end{tabular}

Table 1: The groups studied had similar characteristics before surgery with no statistically significant differences in demographics variables.

\begin{tabular}{|l|c|c|c|}
\hline & Group 1 & Group 2 & P Value \\
\hline Duration of surgery $(\mathrm{min})$ & 92.1 & 86.5 & 0.436 \\
\hline Tourniquet time $(\mathrm{min})$ & 97.4 & 91.7 & 0.320 \\
\hline
\end{tabular}

Table 2: The two groups were statistically comparable in operative time and duration of tourniquet inflation.

\begin{tabular}{|l|c|c|c|}
\hline & Group 1 & Group 2 & P-value \\
\hline $\mathrm{Hb}$ concentration preop & $13.2(12.4-15,8)$ & $12.9(11.8-15.2)$ & 0.735 \\
\hline $\mathrm{Hb}$ concentration postop & $10.8(8.0-12.3)$ & $10.4(7.8-12.6)$ & 0.379 \\
\hline $\begin{array}{l}\text { Hb concentration 5 days } \\
\text { postsurgery }\end{array}$ & $11.6(10.1-12.7)$ & $11.2(10.2-12.3)$ & 0.553 \\
\hline Drainage $(\mathrm{ml})$ & $364+/-186$ & $413+/-175$ & 0.274 \\
\hline Blood loss & $573+/-159 \mathrm{ml}$ & $608+/-132$ & 0.341 \\
\hline Red cells transfused (units) & 1 & 3 & 0.413 \\
\hline Number of patients transfused & 1 & 1 & 0.586 \\
\hline Thromboembolic complications & 2 DVP & $\begin{array}{c}\text { 3 DVP } \\
\text { (1 Doppler +) }\end{array}$ & 0.163 \\
\hline
\end{tabular}

Table 3: The haemoglobin values did not showed statistical significant differences between groups before surgery on the postop or 5 days after the surgery.

\section{Discussion}

There are meta-analysis published studying the results of employing TXA against placebo in TKRconcluding that is an effective drug degreasing blood loss and the needs of transfusionwithout increasing thromboembolic complications [1,2,34-37]

Our results obtained in drainage blood loss and total blood loss is similar to the ones obtained in that meta-analysis.

What is clear is that more than one dose of TXA is needed to be effective [37] and no differences have seen on the good results obtained with the TXA maintaining its administration for more than 24 hours [15].

In our experience, multimodal protocol with TXA administrated in dose of $15 \mathrm{mg} / \mathrm{kg}$ reduces the total bleeding and the drainage blood comparing our results with the obtained in other series where TXA results were measured against placebo[1,2,36-38].

It is use reduces transfusion requirements if we compare our results to the studies published comparing TXA against placebo. TXA reduces the cost of transfusion and avoids its risks.

Treatment with TXA before inflation of the tourniquet did not seem to augment the risk of DVT.

The results obtained in our study allow us to continue using TXA in unilateral TKR procedures to reduce blood total loss, the need of transfusion and knowing that there is no higher risk of thromboembolic complications. We have showed that there is no statistical significant difference in administrating the TXA before inflating or just before deflating the tourniquet so we can continue using it in a dose of $15 \mathrm{mg} /$ $\mathrm{kg}$ during 24 hours postop.

\section{Conclusion}

We conclude that there is no significant difference on blood loss, transfusion requirements and thromboembolic complications after performing a total knee arthroplasty when the tranexamic acid is employed before inflating or just before releasing the tourniquet.

As fibrynolitic activation is a cascade process that is most easily inhibited in its earlier phase, and tranexamic acid has little effect when given after heavy blood loss [39]. We recommend to star administrating it before inflating the tourniquet.

\section{References}

1. Zhang H, Chen J, Chen F, Que W (2012) The effect of tranexamic acidon bloodloss and use of blood products in total knee arthroplasty: a meta-analysis. Knee Surg Sports Traumatol Arthrosc 20: 1742-1752.

2. Yang ZG, Chen WP, Wu LD (2012) Effectiveness and safety of tranexamic acid in reducing bloodloss in total knee arthroplasty: a meta-analysis. J Bone Joint Surg Am 94: 1153-1159. 
Citation: Torres A, Fernández-Fairén M, Vaquero DH (2014) Analysis of the Results on Perioperative Blood Loss after a Total Knee Arthroplasty Employing Tranexamic Acid before or after Inflating the Tourniquet. Surgery Curr Res 4: 171. doi:10.4172/2161-1076.1000171

3. Sehat KR, Evans R, Newman JH (2000) How much blood is really lost in total knee arthroplasty?.Correct blood loss management should take hidden loss into account. Knee 7: 151-155.

4. Woolson ST, Wall WW (2003) Autologous blood transfusion after total knee arthroplasty: a randomized, prospective study comparing predonated and postoperative salvage blood. J Arthroplasty 18: 243-249.

5. Hewitt PE, Llewelyn CA, Mackenzie J, Will RG (2006) Creutzfeldt-Jakob disease and blood transfusion: results of the UK Transfusion Medicine Epidemiological Review study. Vox Sang 91: 221-230.

6. Lemaire R (2008) Strategies for bloodmanagement in orthopaedic and trauma surgery. J Bone Joint Surg Br 90: 1128-1136.

7. Chiaroni J, Legrand D, Dettori I, Ferrera V (2004) Analysis of ABO discrepancies occurring in 35 French hospitals. Transfusion 44: 860-864.

8. Rosencher N, Kerkkamp HE, Macheras G (2003) Orthopedic Surgery Transfusion Haemoglobin European Overview (OSTHEO) study: Blood management in elective knee and hip arthroplasty in Europe. Transfusion 43:459-69.

9. Bierbaum BE, Callaghan JJ, Galante JO, Rubash HE, Tooms RE, et al. (1999) Analysis of Blood management in patients having a total hip or knee arthroplasty. J Bone Joint Surg Am 81: 2-10

10. Cid J, Lozano M (2005) Tranexamic acid reduces allogeneic red cell transfusions in patients undergoing total knee arthroplasty: results of a metaanalysis of randomized controlled trials. Transfusion 45: 1302-1307.

11. Benoni G, Fredin H (1996) Fibrinolytic inhibition with tranexamic acid reduces bloodloss and blood transfusion after knee arthroplasty: a prospective randomised, double-blind study of 86 patients. J Bone Joint Surg Br 78: 434-

12. Camarasa MA, Ollé G, Serra-Prat M, Martín A, Sánchez M, et al. (2006) Efficacy of aminocaproic, tranexamic acids in the control of bleeding during total knee replacement: a randomized clinical trial. Br J Anaesth 96: 576-582.

13. Veien M, Sørensen JV, Madsen F, Juelsgaard P (2002) Tranexamic acid given intraoperatively reduces bloodloss after total knee replacement: a randomized, controlled study. Acta Anaesthesiol Scand 46: 1206-1211.

14. Zohar E, Ellis M, Ifrach N, Stern A, Sapir O, et al. (2004) The postoperativebloodsparingefficacy of oral versus intravenous tranexamic acid after total knee replacement. Anesth Analg 99: 1679-1683.

15. Jansen AJ, Andreica S, Claeys M, D'Haese J, Camu F, et al. (1999) Use of tranexamic acid for an effective blood conservation strategy after total knee arthroplasty. Br J Anaesth 83: 596-601.

16. Fahmy NR, Patel DG (1981) Hemostatic changes and postoperative deep-vein thrombosis associated with use of a pneumatic tourniquet. J Bone Joint Surg Am 63: 461-465

17. Risberg B (1985) The response of the fibrinolytic system in trauma. Acta Chir Scand Suppl 522: 245-271.

18. Hoylaerts M, Lijnen HR, Collen D (1981) Studies on the mechanism of the antifibrinolytic action of tranexamic acid. Biochim Biophys Acta 673: 75-85.

19. Spahn DR, Casutt M (2000) Eliminating blood transfusions: new aspects and perspectives. Anesthesiology 93: 242-255.

20. Hiippala S, Strid L, Wennerstrand M, Arvela V, Mäntylä S, et al. (1995) Tranexamicacid (Cyklokapron) reduces perioperative blood loss associated with total knee arthroplasty. Br J Anaesth 74: 534-537.

21. Horrow JC, Van Riper DF, Strong MD, Grunewald KE, Parmet JL (1995) The dose-response relationship of tranexamicacid. Anesthesiology 82: 383-392.

22. Benoni G, Carlsson A, Petersson C, Fredin H (1995) Doestranexamicacid reduce bloodloss in knee arthroplasty? Am J Knee Surg 8: 88-92.
23. Hiippala ST, Strid LJ, Wennerstrand MI, Arvela JV, Niemelä HM, et al. (1997) Tranexamicacidradicallydecreasesbloodloss and transfusionsassociated with total knee arthroplasty. AnesthAnalg 84: 839-844.

24. Andersson L, Nilsoon IM, Colleen S, Granstrand B, Melander B (1968) Role of urokinase and tissue activator in sustaining bleeding and the management there of with EACA and AMCA. Ann N Y Acad Sci 146: 642-658.

25. Nilsson IM (1980) Clinicalpharmacology of aminocaproic and tranexamicacids. J Clin Pathol Suppl R Coll Pathol 14: 41-47.

26. Kaller H (1967) Intestinal absorption, distribution and elimination of 4-aminomethylcyclohexanecarboxylic acid (AMCHA) and epsilonaminocaproicacid (ACA) in humans. Naunyn Schmiedebergs Arch Exp Pathol Pharmakol 256: 160-168.

27. Good L, Peterson E, Lisander B (2003) Tranexamic acid decreases externa bloodloss but not hidden bloodloss in total knee replacement. $\mathrm{Br} \mathrm{J}$ Anaesth 90: 596-599.

28. Békássy Z, Astedt B (1990) Treatment with the fibrinolyticinhibitortranexamicac id--risk for thrombosis? Acta Obstet Gynecol Scand 69: 353-354.

29. Woo KS, Tse LK, Woo JL, Vallance-Owen J (1989) Massive pulmonary thromboembolism after an examic acid antifibrinolytic therapy. $\mathrm{Br} \mathrm{J}$ Clin Pract 43: 465-466.

30. Endo Y, Nishimura S, Miura A (1988) Deep-vein thrombosis induced by tranexamic acid in idiopathicthrombocytopenic purpura. JAMA 259: 3561-3562.

31. Petaja J, Myllynen P, Myllyla G, Vahtera E (1987)Fibrinolysisafterapplication of a pneumatictourniquet. Acta Chir Scand153: 647-51.

32. Sharrock NE, Go G, Williams-Russo P, Haas SB, Harpel PC (1997) Comparison of extradural and general anaesthesia on the fibrinolytic response to total knee arthroplasty. Br J Anaesth 79: 29-34.

33. Nadler SB, Hidalgo JH, Bloch T (1962) Prediction of blood volume in normal human adults. Surgery 51: 224-232

34. Lisander B, Ivarsson I, Jacobsson SA (1998) Intraoperative autotransfusion is associated with modest reduction of allogeneictransfusion in prosthetic hip surgery. Acta Anaesthesiol Scand 42: 707-712.

35. Alshryda S, Sarda P, Sukeik M, Nargol A, Blenkinsopp J, et al. (2011) Tranexamicacid in total knee replacement: a systematicreview and metaanalysis. J Bone Joint Surg Br 93: 1577-1585.

36. Kagoma YK, Crowther MA, Douketis J, Bhandari M, Eikelboom J, et al. (2009) Use of antifibrinolytic therapy to reduce transfusion in patients undergoing orthopedic surgery: a systematic review of randomized trials. Thromb Res 123 687-696.

37. Orpen NM, Little C, Walker G, Crawfurd EJ (2006) Tranexamic acid reduces early post-operative blood loss after total knee arthroplasty: a prospective randomised controlled trial of 29 patients. Knee 13: 106-110.

38. Levi M, ten Cate JW (1995) [Antifibrinolytictherapy]. Ned Tijdschr Geneeskd 139: 613-617.

39. Koska J, Goodwin S (1993) Management of massivetransfusions. In: AnesthesiologyClinics of North America,vol II No.3,Anesthesia for Otolaryngologic and Head and Neck Surgery. Philadelphia: Saunders 615-36. 